\title{
FEHÉRJE KOMPLETTÁLT GABONATARTALMÚ SZELETEK KIFEJLESZTÉSE ÉS PIACI HELYZETE
}

\author{
Szabad Alex - Trenyik Eszter - Szabó P. Balázs
}

\begin{abstract}
Absztrakt: A sportolók körében a fehérjeporok preferált étrend-kiegészítő terméknek számítanak. Hazánkban számos fehérjekészítmény közül választhatnak a fizikai aktivitást végzők, eltérő minőségben és árban egyaránt. A kutatás során igyekeztünk felmérni sportolók körében a fehérjeporok fogyasztási szokásait, illetve a kapott eredmények alapján a fehérjebevitel formái közül a müzliszeletek jelentőségét is tanulmányoztuk. A kérdőíves felmérésben a 196 válaszadótól kapott információk alapján három különböző növényi (rizs, borsó, szója) és állati (tejsavó, marhahús, tojás) izolátumok mellett döntöttünk, melyekkel müzliszeleteket komplettáltunk. Továbbá alapanyag költséget is meghatároztunk egyszerü osztókalkulációs módszerrel, mely során átlagos piaci nettó árakkal számoltunk, így a fehérjedúsítással átlagosan $103 \mathrm{Ft}$-ra becsülhető 1 adag $(35 \mathrm{~g})$ müzliszelet közvetlen anyagköltsége. Fontos kérdés a termék piaci helyzete, ezért a boltban kapható, hasonló felépítésü termékekkel is összehasonlítottuk a készterméket, hogy megállapíthassuk a tápértékbeli különbségeket is. Meghatározó azonban az egyes allergének jelenléte a termékben, ezért a fogyasztókhoz alkalmazkodva szükségszerü a folyamatos fejlesztés.
\end{abstract}

\begin{abstract}
Protein powders are the preferred dietary supplement among athletes. In our country, there is a wide range of protein products available to people who are physically active, in varying quality and price. In this research, we have tried to assess the consumption habits of protein powders among athletes and, based on the results obtained, we have also studied the importance of muesli bars as a form of protein intake. In the questionnaire survey, based on the information obtained from 196 respondents, three different vegetable (rice, peas, soy) and animal (whey, beef, eggs) isolates were chosen to complete muesli bars. Furthermore, we estimated the cost of the raw materials using a simple fractional costing method based on average net market prices, so that the direct material cost of 1 portion $(35 \mathrm{~g})$ of muesli bars with protein fortification was estimated at $103 \mathrm{HUF}$ on average. The market position of the product is an important issue, so we also compared the finished product with products of similar structure available in the shops to determine the differences in nutritional value. However, the presence of certain allergens in the product is crucial and continuous improvement is necessary to adapt to consumer needs.
\end{abstract}

Kulcsszavak: fehérje, étrend-kiegészítő, sporttáplálkozás, termékfejlesztés

Keywords: protein, dietary supplement, sports nutrition, product development

\section{Bevezetés}

A sporttáplálkozás napjainkban Magyarországon kezd egyre népszerübb tárgykörré válni. A sportolók étkezése az egészséges táplálkozás olyan speciális formája, amelynek fö célja elsősorban a teljesítőképesség növelése és optimalizálása. Manapság egy versenyzőnek igen komoly megpróbáltatásokon kell keresztül mennie, ha jelentős sikerek elérését tüzi ki célul. Ebből adódóan számukra az edzés és a megfelelő étrend kialakítása kulcsfontosságú tényezők.

Minden egyes sportág esetében megoszlik a vélemény a megfelelő és kellő mennyiségü tápanyagbevitelt illetően. Terhelés elött és után számos különbség figyelhető meg a sportolók táplálkozásában. Kiemelten fontos figyelmet érdemel a három alapvető makrotápanyag megfelelő bevitele: a fehérjék, a szénhidrátok és a zsírok. Ezek közül a jelentős kultusszal rendelkezö fehérjekészítmények 
jelentőségére helyezném a hangsúlyt, ugyanis a szervezet fehérjeigénye emelkedik erő és állóképességi edzés hatására, így megkérdőjelezhetetlen annak fogyasztása is.

A nagyméretű piaci kínálat napjainkban meghatározó, nagyon ritkán találja meg egy sportoló egyből a számára leginkább ideális fehérjeport, legyen szó állati vagy növényi eredetüröl. Kutatásunkban a fehérjeporok fogyasztási szokásainak felmérése mellett a kedvelt állati és növényi fehérjeporokat müzliszeletek receptúrájához adagoltuk, hogy figyelemmel kísérjük a sütés és tápértékbeli változásokat, valamint megfelelő tápanyag kiegészítésként szolgáljanak sportolás után is egyszerü snack formájában.

\section{A sporttáplálkozás alapjai}

A táplálkozástudomány egy folyamatosan fejlődő szakterület, hiszen egészségünk, illetve annak védelme minden ember számára egyformán fontos. Az 1. ábrán látható, hogy Magyarország a harmadik helyet foglalja el a legelhízottabb országok között, ami a mozgásszegény életmóddal is részben összefüggésbe hozható. Akik sportolni kezdnek, azoknak egy, a szokásostól eltérő táplálkozási formát szükséges folytatniuk az elérni kívánt cél érdekében, legyen szó fogyásról vagy akár testépítésről. A sportágspecifikus táplálkozásnál célszerü különbséget tenni a terhelési ciklustól függően (versenyre felkészülés, pihenőnapok, verseny utáni időszak), illetve szabadidős vagy ténylegesen versenysportról beszélhetünk. Ezek ismeretében a táplálkozási szokásainkat is tudjuk szükség szerint változtatni vagy igazítani, viszont a globalizáció világában a jelenlegi trendeket is érdemes megismernünk.

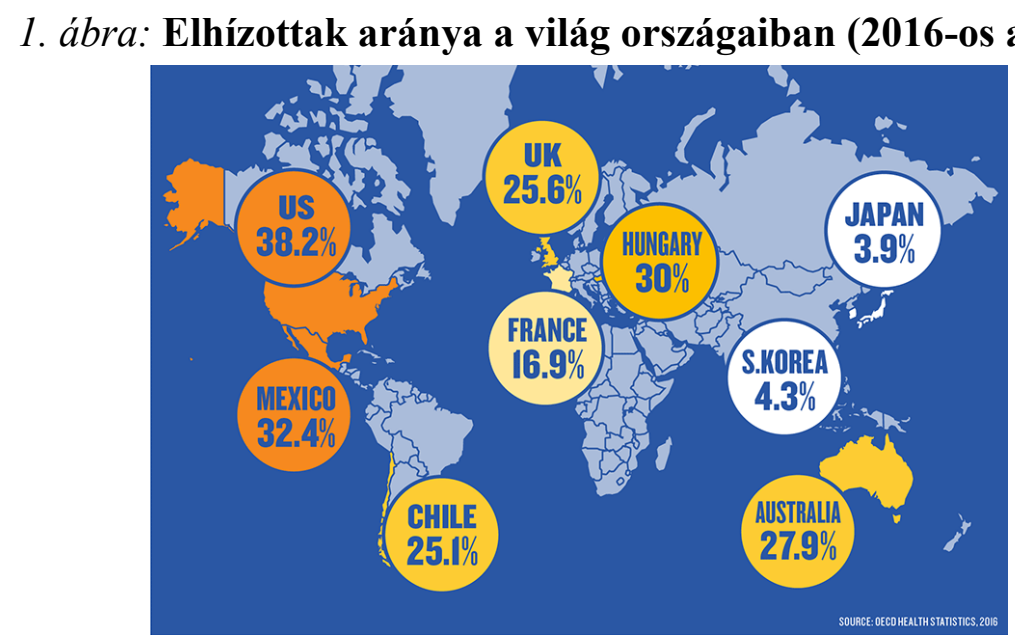

Forrás: http://fna.hu/hir/elhizasellen2017

\subsection{Aktuális táplálkozási trendek (2021)}

Tekintettel a legfrissebb adatokra (khni.kerry.com), a 2021-es élelmiszerfogyasztási tények vonatkozásában 10 különböző trend figyelhetö meg: a fenntartható táplálkozás, a proaktív egészség fogalma, az immunrendszer védelme, a növényi táplálkozás szerepe, az érzelmi alapokon nyugvó étkezés, a fogyasztói 
bizalomkeltés, az időskori fehérjefogyasztás fontossága, az emésztőrendszer egészsége, a fehérjék minőségi és mennyiségi bevitele, valamint a cukrok.

A trendek között megfigyelhető a fehérjebevitel jelentősége. A fehérjék felhasználása sokoldalú, kémiai szempontból aminosavakból felépülő összetett vegyületek. Az aminosavak amino (-NH2) és karboxilcsoportot (-COOH) tartalmaznak. A sejtek vízmentes tömegének közel felét fehérjék teszik ki (Tihanyi, 2014). Két féle aminosavat különböztetünk meg: esszenciális, amelyet a szervezet nem képes elöállítani és nem esszenciális aminosavak. Idöskorban különösen az elágazó láncú aminosavak (például leucin) bevitele célszerü, mivel az izomtömeg az öregedéssel fokozatosan csökken és az idősebb populációban az izomfehérjeszintézis folyamata meghatározó (Baum et al., 2016).

$\mathrm{Az}$ érzelmi alapokon nyugvó étkezés sokak számára prioritássá vált. Az antioxidánsokban, esszenciális zsírsavakban (például Omega-3 zsírsav), vitaminokban és rostban, illetve probiotikumokban gazdag étrend javíthatja a mentális egészséget, ami a sportoláskor is egy lendületet biztosíthat (www.runnersworld.hu). Egészségünk megőrzése érdekében fontos a megelőzés, tehát a diéta csupán átmeneti jellegü javulásokat hozhat, nem pedig a tényleges egészségügyi problémát orvosolja (khni.kerry.com). Ha sikerülne ezt összhangba hozni, azaz effektíve tudnánk életvitelünket úgy alakítani, hogy ne legyen szükségszerü az állandó diéta, akkor beszélhetünk proaktív egészségről. A fogyasztói bizalomkeltés napjainkban egyre inkább kulcsfontosságú, hiszen a vásárlókat jobban foglalkoztatja az általuk választott élelmiszer tápértéke, illetve a mesterséges színezékeket, valamint aromákat is igyekeznek elkerülni. A hiteles származás az étrend-kiegészítőkre is vonatkozik.

\subsection{Fehérjék szerepe a sportban és a fehérjekészítmények}

Habár a sporttáplálkozási termékeket elsősorban a sportolók számára fejlesztették ki, hogy megfelelő kiegészítésként szolgáljanak a tápanyagbevitelt illetően, a mozgásszegény életmódot élők között is akadnak olyanok, akik szívesen fogyasztják. A 37/2004. (IV.26.) ESzCsM rendelet értelmében: étrend-kiegészítő a „hagyományos étrend kiegészítését szolgáló olyan élelmiszer, amely koncentrált formában tartalmaz tápanyagokat vagy egyéb táplálkozási vagy élettani hatással rendelkező anyagokat". Továbbá az étrend-kiegészítők előállításához felhasználható vitaminokat és ásványi anyagokat a rendelet 1 . számú melléklete, mígnem az egyes vitaminok és ásványi anyagok felhasználható formáit a 2 . számú melléklet tartalmazza.

A mikrobiom, a metabolizmus, az etnikai háttér, a nem, az életkor, az étrend, a testmozgás gyakorisága, a földrajzi elhelyezkedés, a gazdaszervezet egyéni fiziológiai jellemzői és egyebek mellett az egyén metabolikus válasza a bevitt fehérjére, mind befolyásoló tényezők a fehérje fogyasztást illetően (Kårlund et al., 2019). A fehérjeszükséglet lényegében két tényezővel magyarázható: az izommunkával és a fokozottabb mértékủ fehérje felhasználásával. A különböző sportágak fehérjeszükségleteit az 1. táblázat tartalmazza. Látható, hogy a legalacsonyabb érték $1,4 \mathrm{~g} / \mathrm{ttkg}$, mígnem a legmagasabb érték $2 \mathrm{~g} / \mathrm{ttkg}$. A táblázatban 
szereplő értékek átlagosak, tehát ettől eltérő értékek is lehetnek. Az állóképességi sportágaknál, a sportjátékoknál, valamint a fejlődésben lévő junior sportolóknál észlelhető az alacsonyabb fehérjeszükséglet tartomány.

\section{1. táblázat: Különböző sportágak fehérjeszükséglete}

\begin{tabular}{|c|c|}
\hline $\mathbf{g} / \mathbf{t t k g}$ & Sportágak \\
\hline $1,4-1,6$ & Állóképességi sportágak \\
\hline $1,6-1,8$ & $\begin{array}{c}\text { Kajak-kenu, evezés, sportjátékok többsége, pályakerékpározás, } \\
\text { teke, vitorlázás, úszás }\end{array}$ \\
\hline $1,8-2,0$ & $\begin{array}{c}\text { Rövidtávfutás, torna, birkózás, cselgáncs, ökölvívás, karate, } \\
\text { akrobatika, gimnasztika, alpesi sí, motorsport, atlétikai } \\
\text { ugrószámok, tíz-és hétpróba }\end{array}$ \\
\hline 2 & Atlétikai dobások, súlyemelés, erőemelés, testépítés \\
\hline $1,5-2,0$ & Fejlődésben lévő serdülő, junior sportoló \\
\hline 2 & Izomtömeg növelö sportoló \\
\hline $1,8-2,0$ & Fogyókúrázó élsportoló \\
\hline
\end{tabular}

Forrás: Silye, 2017

Az aminosav kiegészítők szedésének célja, hogy a nagy terheléssel járó edzés során vagy versenysorozatok idején biztosítsák az izmok regenerálódását, illetve az izomépülést. A legtöbb aminosav kétféle formában létezik, D- és L- módosulatban, de szervezetünk az L-módosulatokat képes könnyebben hasznosítani (Silye, 2017). Ide soroljuk az L-glutamint, amelynek leghasznosabb tulajdonsága, hogy az izmok regenerációs idejét képes lerövidíteni és antikatabolikus hatást is elöidéz. A BCAA elágazó láncú aminosavakat jelent (leucin, izoleucin, valin). Megvédik az izomfehérjéket a lebomlástól, valamint az izomerö és a zsírmentes testtömeg növelésében is nélkülözhetetlen (Silye, 2017). A fehérje-kiegészítők közül a BCAAt tartalmazó termékek iránti igény növekszik egyre inkább a fogyasztók körében (Kårlund et al., 2019).

Napjaink új fehérjeforrásai állati és növényi eredetűek. Ezen belül nem eredetük, hanem aminosav-összetételük határozza meg értékelésüket. Amikor az ételkészítés során a hiányzó aminosav-tartalmú élelmianyagok kiegészülnek teljes értéküvé, akkor komplettálunk. Komplettálás lehet, amikor például egy teljes értékü fehérjével (pl. tejsavófehérje) kiegészítjük az adott termék összetételét. A 2. táblázatban összefoglaltam néhány élelmiszer fehérjetartalmának aminosav összetétele alapján számított táplálkozási értékeit.

Biológiai érték alatt értjük, hogy az adott élelmiszer milyen mértékben tartalmazza az összes esszenciális aminosavat. Minél magasabb ez az érték, annál jobban hasznosul a szervezetben a fehérjeszintézis során. A 2. táblázatban az állati eredetü élelmiszerekről elmondható, hogy magasabb értékkel rendelkeznek a növényiekhez képest. A tojás és az anyatej aminosav összetétele meghatározó, illetve a marhahús és a tejsavófehérje is magas értéket képviselnek. A növényi eredetü fehérjék többsége nem teljes értékü, mert belölük hiányoznak a nélkülözhetetlen aminosavak kisebb-nagyobb mértékben, elsősorban lizinből, metioninból, treoninból és triptofánból fordul elő az alacsonyabb mennyiség (Markovics, 2005). Növényiek 
közül a szójafehérje, a borsó, bab, lencse és a rizsfehérje emelkedik ki. A szójafehérje az összes aminosavból tartalmaz bizonyos mennyiséget, illetve sok lizint, valamint a növényi fehérjék átlagához képest több treonint tartalmaz (Berrazaga et al., 2019).

\section{2. táblázat: Néhány élelmiszer fehérjéjének biológiai értéke}

\begin{tabular}{|c|c|}
\hline Élelmiszer & Táplálkozási érték \\
\hline Anyatej, teljes tojás & 100 \\
\hline Tehéntej & $88-95$ \\
\hline Tehéntejalbumin & 104 \\
\hline Marhahús & $88-92$ \\
\hline Halhús & $90-92$ \\
\hline Edámi sajt & 85 \\
\hline Ementáli jellegü sajt, sertéshús & 84 \\
\hline Csirkehús & 82 \\
\hline Szójafehérje & $74-78$ \\
\hline Burgonya & 73 \\
\hline Bab, borsó, lencse & $56-72$ \\
\hline Rizs & $63-67$ \\
\hline Búzaliszt (83\%-os kiőrlés) & 53 \\
\hline Kukoricaliszt & 49 \\
\hline Földimogyoróliszt & 48 \\
\hline &
\end{tabular}

Forrás: Rodler, 2005

A fogyasztók egy csoportja előnyben részesíti a növényi fehérjéket környezetvédelmi szempontokból, mivel kevesebb üvegháztartású gáz kerül a légkörbe és a növények termelése során a földterületet újból felhasználhatják, ellenben az állattartásnál, ahol a talaj komoly gondozást igényel a jószágok után (Henchion et al., 2017). A hús és állati eredetü készítmények viszont teljes értékü fehérjeforrások és átlagosan $20 \mathrm{~g} / 100 \mathrm{~g}$ a legtöbb hús fehérjetartalma, illetve a 300 kcal-nál kisebb energiatartalmú húsok fogyasztása ajánlott, melyek rendelkezhetnek az előbb említett fehérjeértékkel (Szabó, 2018). Továbbá a fehérjepiacot elsősorban a tej alapú összetevők dominálják, mivel a tejipar különböző membránszeparációs technikákat alkalmaz például a tejsavó szürésére, ami később termékek összetevőjévé válik (Henchion et al., 2017).

Az emésztőrendszer egészségét a tíz trend között is megtalálhatjuk, valamint összefüggésbe hozható az elfogyasztott élelmiszer a jelentkező gyomor és bélrendszeri tünetekkel (khni.kerry.com), mert az egyes élelmiszerek emészthetősége eltérő mértékü. A 2. ábrán a növényi és állati eredetü fehérjék emészthetőségét láthatjuk százalékban kifejezve. Az állati fehérjék mindegyike meghaladja a közel 90\%-os emészthetőségi szintet, ellenben a növényiek, melyek többnyire hüvelyesek, a 60-80\%-os intervallum között mozognak, tehát azokat nehezebben dolgozza fel szervezetünk. Tulajdonképpen ezen adatok is azt mutatják, hogy az állati eredetü fehérjeporokat miért célszerübb alkalmazni és miért preferált annyira a sportolók és a táplálék-kiegészítőket gyártók körében. Elvégre sportolóknál is lényeges, hogy a bevitt fehérje könnyen emészthető legyen és hasznosuljon rövid idő alatt. 
2. ábra: A növényi és állati eredetű fehérjék emészthetősége \%-ban* kifejezve

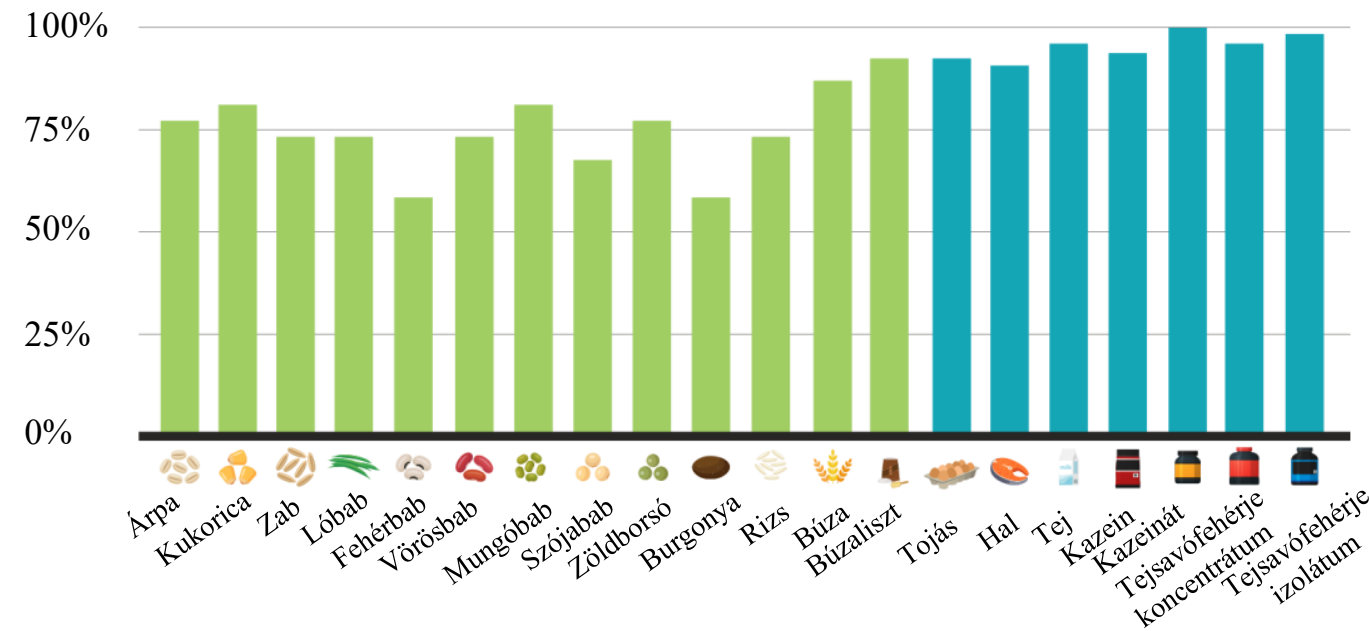

Forrás: https://examine.com/guides/protein-intake/\#ref94

*A FAO adatai alapján számított értékek, 2013

\section{Kérdőíves vizsgálat eredményei}

Jelen kutatás célja, hogy a fehérjeporok fogyasztási szokásait felmérjük, majd a legnépszerübb három állati és növényi fehérjékkel komplettáljunk. A felhasználásra kerülő fehérjeporok kiválasztását egy kérdőíves felméréssel vizsgáltuk 2020 januárjában. A kérdőíves kutatás, vagyis az írásbeli megkérdezés keretében az elektronikus felületre való feltöltést választottuk, amely bárki számára hozzáférést biztosított, illetve a felmérésben 230 válaszadótól kaptunk információkat. Esetemben konkrétan a megkérdezéssel megismerhető vevői szándékok, szokások és vélemények feltárása volt a cél. A primer információkat olyan személyektől nyerjük, akik relevánsak az adott téma szempontjából, ebből is adódik a módszer előnye a szekunder kutatásokkal szemben. Ezen kívül megemlítendő, hogy a vizsgálat eredményeként milyen információk születnek. A kvalitatív jellegüek „minőségi” információkat, míg a kvantitatív jellegü vizsgálatok mennyiségi és számszerüsíthető adatokat tárnak elénk. A megismerés folyamatában a széles körben lefolytatott mennyiségi adatgyüjtés és a szám szerinti adatok kinyerése volt a célunk, amely alapján információkhoz juthattunk.

A kérdőívet kitöltők között nincs szignifikáns különbség a nemek megoszlását tekintve: a nők aránya $44,8 \%$, a férfiaké pedig 55,2\%. A válaszadók életkorát figyelembe véve, legnagyobb számban (37,4\%) a 19-25 éves korosztály képviselték magukat. Ezzel szemben a válaszadók 91,7\%-a hobbisportoló, illetve csekély mértékü $(8,3 \%)$ a versenysportolói tevékenységet üzők részvételi aránya. Továbbá 196 fő fogyaszt fehérjekészítményt és 34 fő nem preferálja ezek fogyasztását, így számukra a kérdőív további kitöltése nem volt lehetséges.

Vizsgálva a válaszadók fehérje fogyasztási szokásait, fontosnak tartottam felmérni a fehérjebevitel különböző formáit (3. ábra). A kérdés tekintetében több válasz megadására volt lehetőség. A válaszadók több, mint $81 \%$-a közel azonos 
arányban választotta az ízesített fehérjepor és a természetes tápanyagforrás lehetőséget, illetve 50\%-uk italok és shakek formájában juttatja szervezetébe a szükséges fehérjéket, ami annak tudható be, hogy ezek könnyebben bevihetők és elkészítésük is egyszerűnek számít. A müzliszeletek (34,7\%) vonatkozásában, melyek egyaránt jelentős fehérjetartalommal is rendelkezhetnek, a magas cukortartalommal kapcsolatos tévhit befolyást gyakorolhat a fogyasztókra. Az ízesítetlen fehérjeporok $(6,1 \%)$ ennek ellenére kevésbé népszerüek. Mivel a müzliszeletek alapból ízesítettek és ezáltal valóban több cukrot tartalmazhatnak, így az ízesítetlen fehérjeporok alkalmazásával kifejleszthetőek magas protein tartalmú müzliszeletek alacsonyabb cukortartalommal.

\section{3. ábra: A fehérjefogyasztás formái $(\mathrm{N}=\mathbf{1 9 6})$}

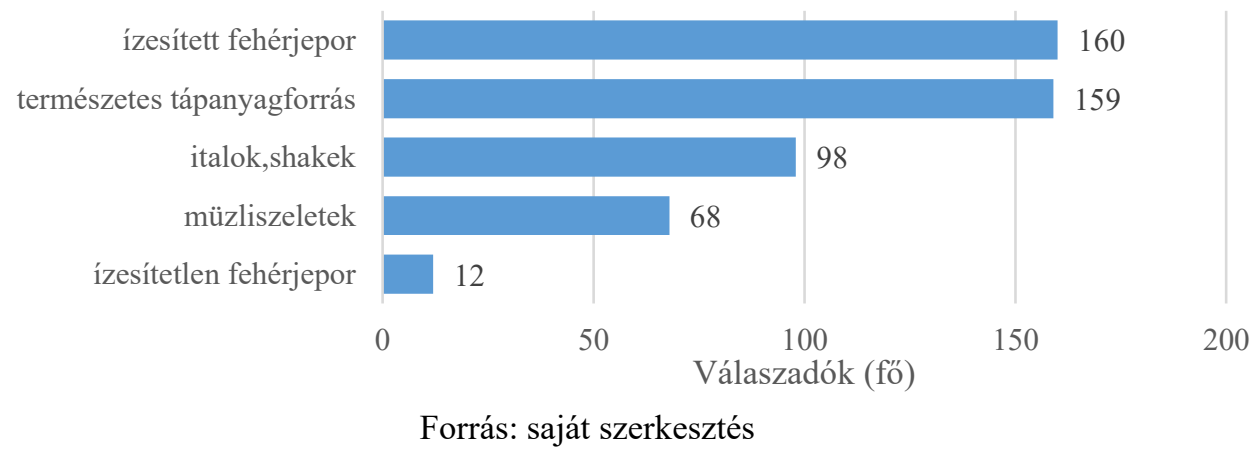

A kérdéseink között szerepelt továbbá, hogy a kitöltők hányféle fehérjeport teszteltek. A válaszadók 62\%-a, azaz 122 fó legfeljebb 10 féle fehérjepor hatását tette próbára, ami azt mutatja, hogy a kitöltők empirikus úton törekszenek a fehérjék saját szervezetükre gyakorolt jótékony hatásait feltérképezni és a számukra legjobban bevált fehérjét választani. A fehérjeporok megítéléseként, a válaszadók jelentős része $(86,7 \%)$ szerint könnyen és gyorsan fogyaszthatók, valamint 138 fö $(70,4 \%)$ álláspontja alapján izomtömeg építéshez is hasznosnak bizonyulnak. Csupán a kitöltők 17,9\%-a tartja drágának és gyorsan fogyó terméknek a fehérjeporokat.

Kerestük a választ továbbá, mely állati eredetű fehérjeporokat preferálják a fogyasztók, ahol ugyancsak több választ jelölhettek meg. A három kedvelt állati fehérje a tejsavófehérje (77\%), a marhahúsfehérje (23\%) és a tojásfehérje $(21 \%)$ voltak (4. ábra). A tejsavófehérjék jelentős arányának oka, hogy teljes értékü fehérjék, azaz a szervezetben való hasznosulásuk kimagasló mértékü, illetve gyakrabban láthatjuk öket az egyes üzletekben. Ugyancsak a marhahúsfehérje táplálkozási értéke kiemelkedően magas (kb. 90), a tojásfehérje pedig teljes értékü (biológiai értéke 100). A kazein fehérje (11,7\%) alacsony arányának lehetséges oka, hogy lassabban szívódik fel más fehérjével szemben, viszont hosszú ideig képesek ellátni szervezetünket aminosavakkal az alvás ideje alatt is. 
4. ábra: Állati eredetű fehérjeporok népszerüsége (N=196)

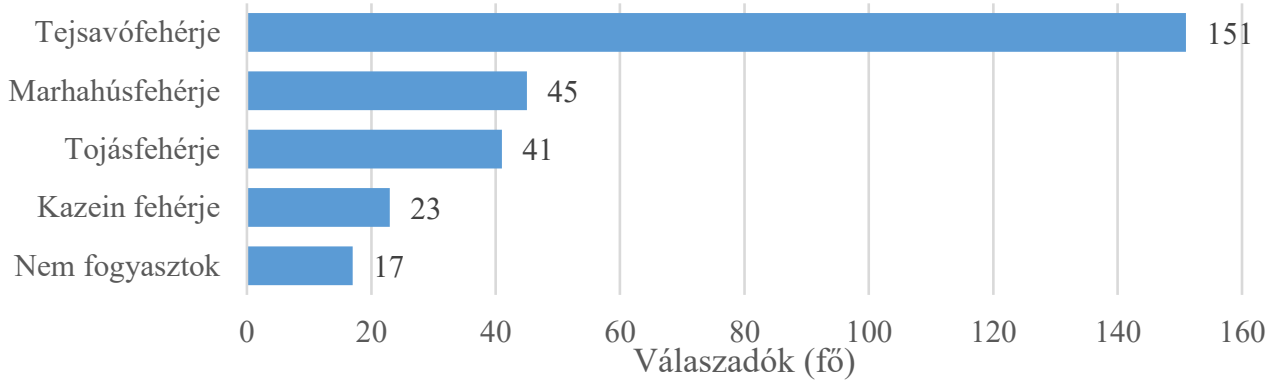

Forrás: saját szerkesztés

Ezenkívül felmértem a növényi eredetü fehérjeporok fogyasztási szokásait is. A 3 legkedveltebb termék a rizsfehérje (24,5\%), borsófehérje (15,3\%) és a szójafehérje $(8,2 \%)$ voltak (5. ábra). A növényi fehérjék kedveltségének oka, hogy a mai világban megemelkedett azon férfiak és nők száma, akik valamilyen allergiával küzdenek, így számukra csak ezek jöhetnek szóba. A rizsfehérje, borsófehérje és szójafehérje pedig mind ugyancsak jelentős táplálkozási értékkel rendelkeznek. A kókuszfehérje és a szójafehérje közötti hasonló arány eredményeképp a szójafehérjét érdemes alkalmazni a továbbiakban, hiszen a kókuszfehérje jellegzetes ízzel rendelkezik és bárki számára könnyen felismerhetö. Ezenfelül a válaszadók jelentős része $(62,3 \%)$ nem fogyaszt növényi fehérjét, ami azzal indokolható, hogy táplálkozástani szerepük jóval alacsonyabb egy állati eredetủ fehérjéhez képest.

\section{5. ábra: Növényi eredetű fehérjeporok népszerüsége $(\mathrm{N}=196)$}

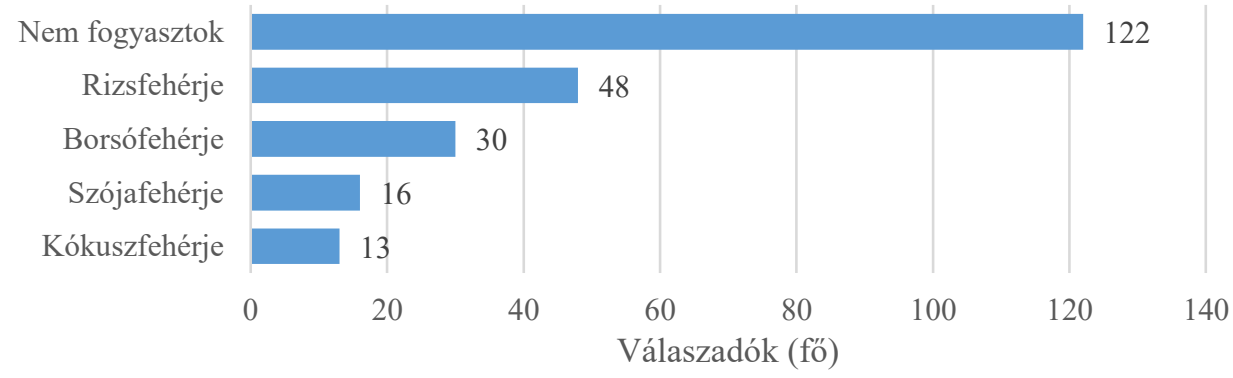

Forrás: saját szerkesztés

\section{Termékfejlesztés, alapanyag költség számítás és piaci helyzet}

A kérdőíves felmérés eredményéből adódóan a kiválasztott három növényi (rizs, borsó, szója) és állati (tejsavó, marhahús, tojás) fehérjével, azonos mennyiségben (32 g) dúsítottuk az előzetesen kipróbált receptet. A szeletek makró tápértékeit Kjeldahl (fehérje), MSZ 20900-2:1987 szabvány szerinti Soxtech (zsír) és MSZ 20900-5:1989 alapján Schoorl-Regenbogen (cukor) módszerrel határoztuk meg. 


\subsection{Termékfejlesztés}

A komplettálni kívánt termék receptúrájában nagy mennyiségben szerepeltek a gabonákat tekintve zabpehely, diófélék, az olajos magvak közül pedig napraforgómag, chiamag és tökmag. Az édes és harmonikus ízért a kakaópor és az aszalványok feleltek (sárgabarack, vörös áfonya). Az állománykialakítást a mogyoróvaj biztosította, melynek ugyan magas a zsírtartalma, de számos, egészséges zsírsavban bővelkedik (például az Omega- 6 telítetlen zsírsavak).

Az alaprecept többszöri kísérletezése után a kiválasztott fehérjékkel dúsítottuk a terméket. A 6. ábrán látható, hogy legmagasabb cukortartalommal a rizsfehérjés $(14,87 \mathrm{~g} / 100 \mathrm{~g})$, legalacsonyabb értékkel a tojásfehérjés szelet $(11,96 \mathrm{~g} / 100 \mathrm{~g})$ rendelkezik. Továbbá a tojásfehérjével dúsított termék zsírtartalma kiemelkedö $(23,86 \mathrm{~g} / 100 \mathrm{~g})$, valamint a szójafehérjés mutatta a legalacsonyabb értéket $(20,2$ $\mathrm{g} / 100 \mathrm{~g})$. A marhahúsfehérjés szeletek pedig jelentős mennyiségben bővelkednek fehérjében $(18,81 \mathrm{~g} / 100 \mathrm{~g})$. Az állati fehérjékkel könnyebb volt dolgoznom, nem igényelt extra kiegészítést és a massza könnyedén összeállt. Ellenben a növényi fehérjés szeleteknél már más volt a helyzet: jóval több vizet igényeltek és a szerkezetük is igencsak morzsalékos volt. Figyelembe vett szempont az értékelésnél az egyes fehérjék biológiai értékei is.

\section{6. ábra: A kifejlesztett szeletek makró tápértékei (g/100g)}

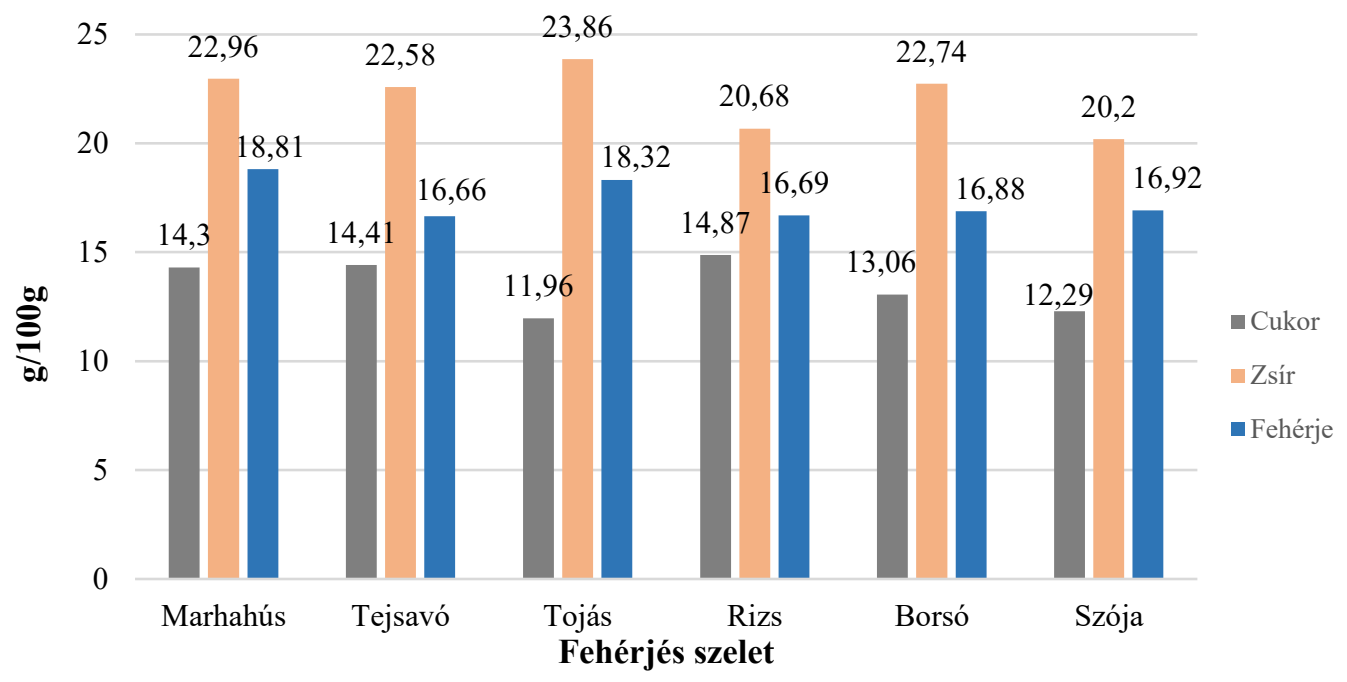

Forrás: saját szerkesztés

\subsection{Alapanyag költség számítás}

A kifejlesztett szelet gyártásához megadható az egyes alapanyagok felhasználásának anyagköltség normája, ami a várhatóan felhasznált mennyiség és az alapanyag tervezett beszerzési árának szorzata, nettó mennyiségben kifejezve (3. táblázat). A kalkuláció során a termelés megkezdése előtt először elkészítjük a termék receptjét (vagy felülvizsgáljuk a már meglévő receptet), illetve számba vesszük a különböző 
anyagszükségleteket. A közvetlen anyagköltség normája változhat az anyagár ingadozása miatt.

A 3. táblázatban szereplő alapanyagok egységárát úgy számoltam ki, hogy minden termék esetében, elektronikus úton kikeresett három legkedvezőbb egységárat átlagoltam. Az alapanyag felhasználás tekintetében a receptúra alapján számoltam ki az $1 \mathrm{~kg}$ massza felhasználásához szükséges kilogrammnyi anyagszükségletet. Végül a két oszlop szorzatával megkaptam a közvetlen anyagköltséget, ami összesen 2627 Ft/kg massza. Ennek következtében 1 adag (35 g) müzliszelet átlagos közvetlen anyagköltsége 92 Ft-ra becsülhetö, ehhez viszont még az egyéb közvetett (például: marketing, pénzügy és számvitel, reklám stb.) és közvetlen költségek (például: bérköltség, üzemi általános költség, selejtveszteség stb.) is hozzászámítandók.

3. táblázat: A kifejlesztett szelet közvetlen anyagköltség számítása átlagos nettó árban kifejezve

\begin{tabular}{|c|c|c|c|}
\hline Megnevezés & $\begin{array}{l}\text { Alapanyag átlagos } \\
\text { egységára (Ft/kg) }\end{array}$ & $\begin{array}{l}\text { Alapanyag } \\
\text { felhasználás } \\
\text { (kg/kg massza) }\end{array}$ & $\begin{array}{l}\text { Közvetlen } \\
\text { anyagköltség } \\
\text { (Ft/kg massza) }\end{array}$ \\
\hline Diófélék keveréke & 5005,2 & 0,233 & 1166,2 \\
\hline Aszalt sárgabarack & 1940,4 & 0,116 & 225,0 \\
\hline Aszalt vörös áfonya & 2761,3 & 0,116 & 320,3 \\
\hline Zabpehely & 545,3 & 0,163 & 88,9 \\
\hline Mogyoróvaj & 2689,8 & 0,140 & 376,6 \\
\hline Eritrit & 1677,1 & 0,093 & 156,0 \\
\hline Chiamag & 2309,5 & 0,023 & 53,1 \\
\hline Héj nélküli tökmag & 3100,4 & 0,023 & 22,3 \\
\hline Hántolt napraforgómag & 968,0 & 0,023 & 147,4 \\
\hline Kakaó & 2105,0 & 0,070 & 2627,1 \\
\hline Összesen & 23102,0 & 1,000 & \\
\hline
\end{tabular}

Forrás: saját szerkesztés

A 4. táblázatban a fehérjedúsítás és a késztermék közvetlen nettó anyagköltségét tüntettük fel. Mivel mindegyik fehérjeporból azonos mennyiségben adagoltunk a masszához, így a különböző állati és növényi fehérjeporok dúsításával előállított 1 adag $(35 \mathrm{~g})$ müzliszelet nettó közvetlen anyagköltsége kiszámolható, amely átlagosan $103 \mathrm{Ft}$. A fehérjedúsítás $1 \mathrm{~kg}$ massza elöállítására fordított közvetlen anyagköltség meghatározását követően a kapott összegeket hozzáadtuk a 3. táblázat alapján kiszámolt összes közvetlen anyagköltséghez, majd ennek ismeretében 1 adagra (35 g) kiszámoltuk a végleges közvetlen anyagköltséget, amely ár a közvetett és közvetlen költségeknek köszönhetően jelentősen növekedhet még. 
4. táblázat: Fehérjedúsítás és a késztermék közvetlen anyagköltsége

\begin{tabular}{|c|c|c|c|c|}
\hline Megnevezés & $\begin{array}{l}\text { Alapanyag } \\
\text { átlagos } \\
\text { egységára } \\
(\mathbf{F t} / \mathbf{k g}) \\
\end{array}$ & $\begin{array}{c}\text { Alapanyag } \\
\text { felhasználás } \\
\text { (kg/kg } \\
\text { massza) }\end{array}$ & $\begin{array}{c}\text { Közvetlen } \\
\text { anyagköltség } \\
\text { (Ft/kg massza) }\end{array}$ & $\begin{array}{c}1 \text { adag }(35 \mathrm{~g}) \text { szelet } \\
\text { nettó közvetlen } \\
\text { anyagköltsége } \\
(\mathrm{Ft} / \mathrm{db})\end{array}$ \\
\hline Tejsavófehérje & 4764,4 & \multirow{6}{*}{0,069} & 328,7 & 103,5 \\
\hline Marhahúsfehérje & 5506,5 & & 380,0 & 105,3 \\
\hline Tojásfehérje & 4519,6 & & 311,9 & 102,3 \\
\hline Borsófehérje & 4142,8 & & 285,9 & 102,0 \\
\hline Rizsfehérje & 5792,7 & & 399,7 & 106,0 \\
\hline Szójafehérje & 2360,4 & & 162,9 & 97,7 \\
\hline
\end{tabular}

Forrás: saját szerkesztés

\subsection{Piaci helyzet felmérése}

Az 5. táblázatban a mért beltartalmi értékek (makrotápanyagok) átlagával számolva a kifejlesztett proteines szeletet összevetettem a boltban kapható, hasonló felépítésü termékekkel, mely jelölés kifejezése és feltüntetése a 1169/2011/EU rendelet XV. számú melléklete alapján került kidolgozásra. Kalkulált eredmények az energia értékek, a só-, és rosttartalom, valamint a telített zsírsavak és szénhidrátok mennyisége. Az 5. táblázatban a jelenleg is forgalmazott müzliszeletek mindegyike magvakkal vagy gyümölcsökkel dúsítottak, mint a kifejlesztett termék. A Cerbona Sport Energy esetében a magvas-gyümölcsös szelet tápértékével számoltam. A termékünkkel kapcsolatban megállapítható, hogy egy fogyasztási egységre nézve $(35 \mathrm{~g})$ a fehérjetartalma azonosnak tekinthető a Nuts\&Fruits termékkel, viszont a Magic Bar mogyorós-karamellás szelet értéke kiemelkedő, de a Cerbona Sport Energy értékét felülmúltuk. Alacsony cukortartalmat is sikerült elérnünk, valamint a termékünk zsírtartalma viszonylag magas, de mindez a telítetlen zsírsavaknak tudható be. Látható még, hogy csupán 1,6 g telített zsírsavat tartalmaz, ami a többi termékkel összevetve a legalacsonyabb. Energiaértéke pedig közel hasonló a többi termékhez képest. Így tehát sikerült egy olyan terméket előállítani, amely alacsony cukortartalommal rendelkezik, bővelkedik esszenciális zsírsavakban, antioxidánsokban és a fehérjetartalma is jelentős. Továbbá a kiszerelési mennyiséget 50 g-ra is lehetne emelni, így egy szelet 9 gramm fehérjét tartalmazna, valamint a rostdúsítás is célravezető lehet. Eladási ár tekintetében, a kifejlesztett termék megközelítőleg 200 Ft-os áron értékesíthető, mely magában foglalja a közvetlen anyagköltséget, illetve a kiskereskedői és nagykereskedői árrést is. A többi szelet eladási árával összehasonlítva (hivatalos honlapjaikról vett adatok, 2021.06.05.), láthatók a jelentős különbségek, viszont egy újonnan kifejlesztett terméket kezdetben nem célszerü magas áron eladásra kínálni, hogy figyelemmel kísérhessük a fogyasztók hozzáállását a termékhez. 
5. táblázat: A kifejlesztett szelet és a bolti müzliszeletek összehasonlító táblázata

\begin{tabular}{|l|c|c|c|c|c|c|c|c|}
\hline \multicolumn{1}{|c|}{$\begin{array}{c}\text { Átlagos } \\
\text { tápértékek }\end{array}$} & \multicolumn{2}{|c|}{$\begin{array}{c}\text { Kifejlesztett szelet } \\
\mathbf{3 5} \mathbf{g}(\mathbf{2 0 0} \mathbf{~ F t )}\end{array}$} & \multicolumn{2}{c|}{$\begin{array}{c}\text { Cerbona Sport } \\
\text { Energy 35 g } \\
\mathbf{( 2 2 9}\end{array}$} & \multicolumn{2}{c|}{$\begin{array}{c}\text { Nuts\&Fruits } \\
\text { BioTechUSA 40 g } \\
(\mathbf{2 9 0} \text { }\end{array}$} & \multicolumn{2}{c|}{$\begin{array}{c}\text { Magic Bar protein } \\
\text { szelet 45 g (490 Ft) }\end{array}$} \\
\hline $\begin{array}{l}\text { Fogyasztási } \\
\text { egység }\end{array}$ & $100 \mathrm{~g}$ & $35 \mathrm{~g}$ & $100 \mathrm{~g}$ & $35 \mathrm{~g}$ & $100 \mathrm{~g}$ & $40 \mathrm{~g}$ & $100 \mathrm{~g}$ & $45 \mathrm{~g}$ \\
\hline $\begin{array}{l}\text { Energia } \\
\text { (kJ/kcal) }\end{array}$ & $1817 / 434$ & $635 / 152$ & $1845 / 440$ & $646 / 154$ & $2115 / 505$ & $846 / 202$ & $1517 / 362$ & $675 / 161$ \\
\hline Zsír (g) & 22 & 7,7 & 18,8 & 6,6 & 29 & 12 & 13 & 5,7 \\
\hline $\begin{array}{l}\text { - amelyböl } \\
\text { telített } \\
\text { zsírsavak (g) }\end{array}$ & 4,5 & 1,6 & 5,3 & 1,9 & 9,2 & 3,7 & 7,5 & 3,4 \\
\hline $\begin{array}{l}\text { Szénhidrát } \\
\text { (g) }\end{array}$ & 37 & 13 & 56,3 & 19,7 & 48 & 17 & 36 & 16 \\
\hline Cukrok (g) & 13,5 & 4,7 & 15,9 & 5,6 & 37 & 15 & 7,5 & 3,4 \\
\hline Rost (g) & 4,6 & 1,61 & 4,8 & 1,7 & 6 & 2,4 & 2,1 & 0,9 \\
\hline Fehérje (g) & 17,4 & 6,1 & 10 & 3,5 & 16 & 6,2 & 33 & 15 \\
\hline Só (g) & 0,22 & 0,07 & 0,28 & 0,10 & 0,10 & 0,04 & 0,50 & 0,22 \\
\hline
\end{tabular}

Forrás: saját szerkesztés

\section{Következtetések, összegzés}

A kérdőíves felmérés eredményeiből adódóan az állati eredetű fehérjeporok igencsak népszerüek, ugyanakkor a növényiek már kevésbé preferáltak. A kitöltők körében a 19-25 éves korosztály képviselték magukat legnagyobb számban, illetve 122 fő a válaszadók közül már több mint 10 féle fehérjeport próbált, tehát van kereslet irántuk. Ha a piacot nézzük, a növényi fehérjék jóval olcsóbbak, viszont nehezebben is emészthetők. A fehérjedúsítás kivitelezése por formájában egyszerübbnek tünik, viszont az eltérö fehérjék aminosav összetétele erösen befolyásoló hatású. A növényi fehérjék kevésbé tartalmaznak annyi esszenciális aminosavat, mint egy állati fehérje, ezért a további természetes fehérjeforrásokkal való kiegészítést is célravezetőnek tartottam termékfejlesztéskor a megfelelő szerkezet kialakítás érdekében. A szeletek receptúrájából kiindulva, gluténmentes zabpehely alkalmazásával gluténérzékenyek is fogyaszthatják a terméket, illetve fokozott figyelmet érdemel az allergének további csökkentése is.

A magas fehérje- és az alacsony cukortartalom további fejlesztése a kiváló értékü alapanyagok megválasztásában, valamint a növényi és állati fehérjeporok mixelésében rejlik. Így további termékfejlesztéssel többféle módon pozícionálhatjuk a terméket. Emellett célszerübb lenne jobban megvizsgálni a versenysportolók fehérjefogyasztási szokásait, mivel a kitöltők csupán 8,3\%-ában képviselték magukat.

Kutatásunk során bebizonyosodott a különböző fehérjékkel dúsított szeletek elönyös és kritikusabb tulajdonságai, melynek következtében témám további utánajárást igényel. Ennek ellenére a kísérletem segíthet a fehérjekészítmények népszerüsítésében és a lehetőségek további feltárásában. 


\section{Köszönetnyilvánítás}

Köszönjük ezúton is Dr. Szabó P. Balázs tanár úr segítségét, aki szakértelmével és hasznos magyarázataival támogatást nyújtott nekem, illetve Szabó László egyéni vállalkozó értékes szakmai és baráti jellegü tanácsait, amelyekkel az elmúlt évek során ellátott.

\section{Irodalomjegyzék}

37/2004. (IV. 26.) ESzCsM rendelet az étrend-kiegészítőkről

Baum, J., Kim, I.-Y., \& Wolfe, R. (2016): Protein Consumption and the Elderly: What Is the Optimal Level of Intake? Nutrients, 8(6): 359.

Berrazaga, I., Micard, V., Gueugneau, M., Walrand, S. (2019): The Role of the Anabolic Properties of Plant- versus Animal-Based Protein Sources in Supporting Muscle Mass Maintenance: A Critical Review. Nutrients, 11 (8): 1825.

Európai Parlament és Tanács 1169/2011/EU rendelete (2011. október 25.) a fogyasztók élelmiszerekkel kapcsolatos tájékoztatásáról, 1924/2006/EK és az 1925/2006/EK európai parlamenti és tanácsi rendelet módosításáról és a 87/250/EGK bizottsági irányelv, a 90/496/EGK tanácsi irányelv, az 1999/10/EK bizottsági irányelv, a 2000/13/EK európai parlamenti és tanácsi irányelv, a 2002/67/EK és a 2008/5/EK bizottsági irányelv és a 608/2004/EK bizottsági rendelet hatályon kívül helyezéséröl

Henchion, M., Hayes, M., Mullen, A., Fenelon, M., Tiwari, B. (2017): Future Protein Supply and Demand: Strategies and Factors Influencing a Sustainable Equilibrium. Foods, 6 (7): 53.

Kårlund, A., Gómez-Gallego, C., Turpeinen, A. M., Palo-oja, O.-M., El-Nezami, H., Kolehmainen, M. (2019): Protein Supplements and Their Relation with Nutrition, Microbiota Composition and Health: Is More Protein Always Better for Sportspeople? Nutrients, 11 (4):829.

Markovics E. (2005): Élelmiszeripari adalékanyagok és tápértéknöveló anyagok. Szegedi Egyetemi Kiadó, Juhász Gyula Felsőoktatási Kiadó, Szeged.

Rodler I. (2005): Élelmezés- és táplálkozásegészségtan. Medicina Könyvkiadó Rt., Budapest.

Silye G. (2017): Sporttáplálkozás a maximális teljesitményhez: táplálkozási kézikönyv sportolóknak. ExSol-Group Kft., Budapest.

Szabó P. B. (2018): Élelmiszerek és az egészséges táplálkozás. TÁMOP-4.1.1.C-12/1/KONV-2012$0014<$ http://eta.bibl.u-szeged.hu/716/1/elelmiszerek_es_az_egeszseges_taplalkozas_teljes. $\operatorname{pdf}>(2021.02 .17$.)

Tihanyi A. (2014): Teljesitményfokozó sporttáplálkozás. Krea-Fitt Kft., Budapest.

$<$ https://examine.com/guides/protein-intake/\#ref94> (2021.02.17.)

$<$ https://khni.kerry.com/trends-and-insights/ten-key-health-and-nutrition-trends-of-this-year/> (2021.02.13.)

$<$ https://www.runnersworld.hu/taplalkozasi-trendek-2021-ben135612-135612> (2021.02.17.) 